\title{
Rola ornamentu w kształtowaniu przestrzeni architektonicznej na przykładzie dekoracji sztukatorskich przypisanych warsztatowi Giovanniego Battisty Falconiego (cz. 2)
}

\author{
Beata Klimek \\ https://orcid.org/0000-0002-4664-283X \\ b.klimek@pollub.pl \\ Katedra Konserwacji Zabytków, Wydział Budownictwa i Architektury, Politechnika Lubelska
}

\begin{abstract}
Streszczenie: W artykule przedstawiono rolę jaką pełnią wybrane rodzaje ornamentów sztukatorskich w kształtowaniu przestrzeni wnętrz przez nie zdobionych. Opisano charakterystyczne rodzaje ornamentów występujące w sztukateriach w XVII w. w Małopolsce. Dekoracyjny i wieloraki ornament jest podporządkowany rodzajom sklepień zdobionych wnętrz. Do zilustrowania tych powiązań posłużono się ornamentami stosowanymi w dekoracjach sztukatorskimi przypisanymi warsztatowi Giovanniego Battisty Falconiego.
\end{abstract}

Słowa kluczowe: ornament, sztukaterie, warsztat sztukatorski, Giovanni Battista Falconi

\section{Uwaga metodyczna}

Niniejsza publikacja „Rola ornamentu w kształtowaniu przestrzeni architektonicznej na przykładzie dekoracji sztukatorskich przypisanych warsztatowi Giovanniego Battisty Falconiego." Cześć 2 stanowi kontynuacje części 1 "Rola układów kompozycyjnych w kształtowaniu przestrzeni architektonicznej na przykładzie dekoracji sztukatorskich przypisanych warsztatowi Giovanniego Battisty Falconiego"

\section{Wstęp}

Bogaty i zróżnicowany ornament dekoracji sztukatorskich warsztatu Falconiego podporządkowany jest zwykle tektonice sklepień, którą równocześnie podkreśla. Wyjątkowo tylko przy zdobieniu niektórych sklepień krzyżowych i kopuł zastosowano ornament, jako element podziału. Jedynie w nielicznych wnętrzach bogactwo i zróżnicowanie motywów ornamentalnych, oraz sposobów ich opracowania zaciera i czyni mniej czytelną tektonikę sklepień, jak to ma miejsce np. w baszcie zamkowej Baranowie i refektarzu w eremie w Rytwianach.

Przy sklepieniach kolebkowych ornament często zbudowany jest symetrycznie względem osi sklepienia. Każde takie przęsło czy pole kompozycyjne zdobią podobne motywy ornamentalne, one rytmizują sklepienie na zasadzie powtarzalności, czy przemienności pewnego zestawu ornamentalnego, jak na przykład w nawie głównej kościoła w Rytwianach. 
Wśród wielości typów ornamentu trzy - kartusz, arabeska i figura ludzka, kiście owoców zawieszone na wstęgach - są motywami przewodnimi dekoracji sztukatorskiej w działalności warsztatu Falconiego i pełnią równocześnie istotne funkcje w poszczególnych schematach kompozycyjnych.

Figura ludzka służy najczęściej zasadniczemu podziałom kompozycji, laurowy wałek podkreśla często ten podział poprzez akcentowanie szwów sklepiennych, a kartusz wypełnia wydzielone w ten sposób pola będąc w ich centrum i podporządkowując sobie resztę motywów ornamentalnych.

Nie można jednak uważać pewnych typów ornamentu, na stałe związanych z określonymi układami kompozycyjnymi, występują one, bowiem we wszystkich schematach kompozycyjnych. Podobnie nie da się stwierdzić, by konkretnych dekoracjach lub jedynie w określonym czasie warsztat Falconiego stosował repertuar ornamentalny tylko dla nich charakterystyczny. Ornament stosowany przy komponowaniu poszczególnych dekoracji różnił się jedynie w sposobie opracowania i pewnych detalach, ale nie w zasadniczym wyglądzie i pełnionej funkcji. Nie sposób omówić wszystkie motywy ornamentalne występujące w dekoracjach przypisanych przez historyków sztuki warsztatowi Falconiego, wyszczególnione zostały jedynie te najbardziej istotne i najczęściej stosowane.

\section{Motywy abstrakcyjne}

W grupie tej spotykamy się z ornamentem cekinowym i „zawijanym”, a także ornamentem geometrycznym reprezentowanym przez astragal, wole oczka. Jednak wśród motywów tej grupy wyróżnia się kartusz. Z tym motywem wiąże się najczęściej ornament zawijany i ornament chrząstkowo-małżowinowy, który w odróżnieniu od pozostałych może być pomocny przy datowaniu dekoracji sztukatorskich.

Kartusz jest najbardziej popularnym motywem opisywanych dekoracji sztukatorskich, towarzyszy im od pierwszych realizacji z lat 40-tych do ostatnich z lat 60-tych. Na początku suchy wykonany jakby z blachy w późniejszych dekoracjach plastyczny i mięsisty, zwinięty w duże precyzyjnie modelowane woluty często wzbogacone o groteskowe maski. W dekoracjach tych pełnił on trojaką funkcje.

Przede wszystkim jest pierwszoplanowym dopełnieniem niektórych układów kompozycyjnych. Kartusz, jako motyw przewodni dekoracji pojawia się głównie w tych sztukateriach, które powiązane są ze sklepieniami kolebkowymi, o podziałach ukośnych, wypełniając ich pola lunetowe i między lunetowe (Rytwiany nawa główna i kaplice boczne). Usytuowany pośrodku nich podporządkowuje sobie inne detale ornamentalne, które mu towarzyszą.

Popularny jest również w tych układach kompozycyjnych, które wiążą się z wnętrzami czterościennymi o sklepieniach krzyżowych i kopułach (Kraków, Łańcut, Baranów Sandomierski, Krosno, Podkamień, Lublin). W układach tych komponowany dośrodkowo, towarzyszy ramom centralnym lub jak w kopułach wypełnia wyznaczone mu pola. W wielokrotnie kartusz jest motywem dzielącym kopułę.

Kartusz jest również samodzielnym motywem, w tym wypadku najczęściej stanowi ramę dla przedstawień heraldycznych wtedy towarzyszą mu postacie aniołów, puttów, które go podtrzymują (Niepołomice, Krosno, Podkamień, Lublin) w końcu kartusz bywa częścią innego, zasadniczego motywu ornamentalnego - najczęściej, na przykład w kościele Łowiczu, towarzyszy wici roślinnej, której bieg przerywa urozmaicając jej dukt.

Przez całą I poł. XVII w. wystrój wewnętrzny kartusza przebiera formy sercowe, czasami bardzo spłaszczone, trójliścia pojedynczego lub zwielokrotnionego i w kilku wypadkach lancetowate zakończonego oraz zniekształconego owalu. Przez cały wspomniany okres jego rama jest zazwyczaj niezbyt szeroka i zwarta, tylko w kaplicy w Niepołomicach kartusz połączony jest z innymi detalami ornamentalnymi ma rozmyty kontur zewnętrzny.

Od początku dolną szeroką podstawę ramy kartusza wzbogacano podwieszonymi do niej pękami owocowymi i girlandami oraz wyrastającą z nich wicią roślinną. Od tego momentu po bokach kartusza pojawiły się również putta, które z jego ram wyrastają lub o nie podpierając się, równocześnie trzymają kartusz. Ramy kartusza formowano dwojako. Ornament zawijany zbudowany jakby z ostro ciętych listew, czasami wzajemnie się przenikających, tworzy ramę kartusza, która wielokrotnie ma ażurowe, geometryczne wycięcia (Lublin) lub też modelowany jest płynnie, łagodnie i wtedy wystające, jakby na zewnętrz ramy jego elementy są zwinięte ciasno rulon (Rzeszów, Krosno). Pojawia się drugi typ kartusza, którego ramy albo całkowicie zbudowane są z akantu (jak w kaplicy Niepołomicach) albo też są proste, czasami wewnątrz sfalowane lub kanelowane lub uzupełnione od zewnątrz akantem (pojedynczymi jego liśćmi lub wicią). 


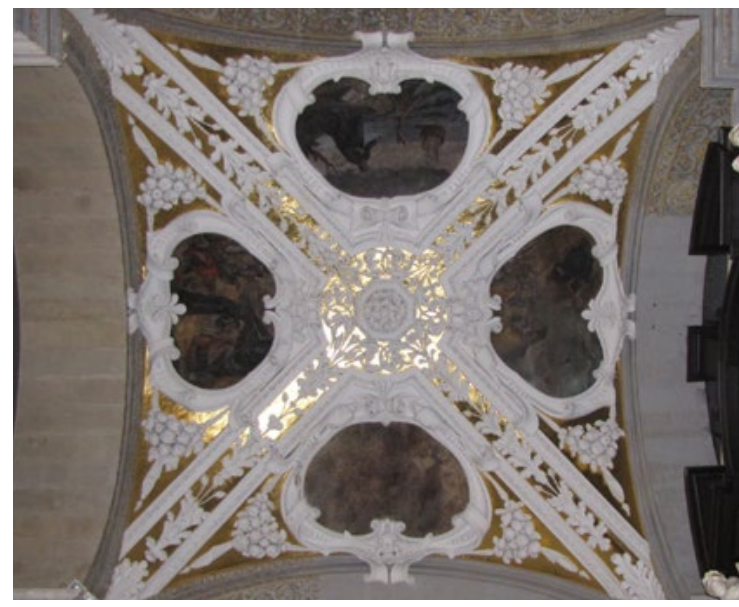

Ryc. 1. Kraków, kościół ss. Piotra i Pawła, sklepienie kaplicy pw. Męki Pańskiej

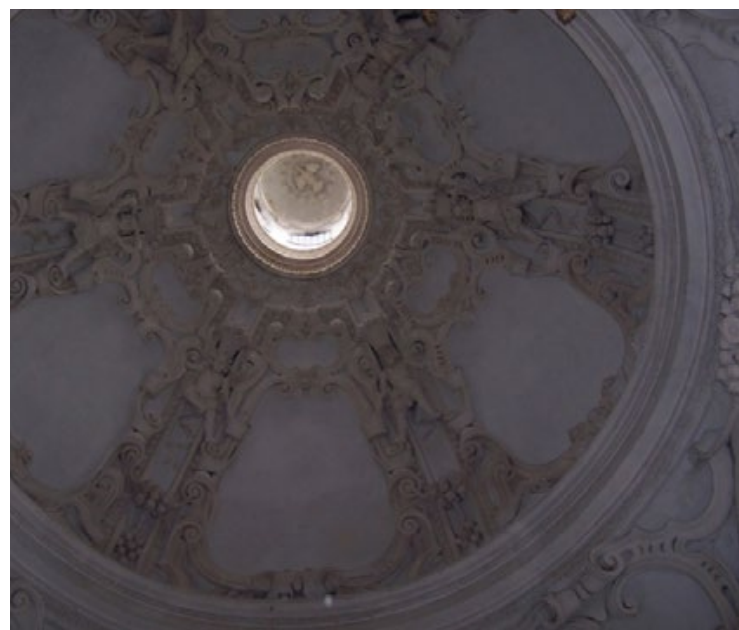

Ryc. 3. Krosno, kaplica Oświęcimów pw. Najśw. Marii Panny i św. Stanisława

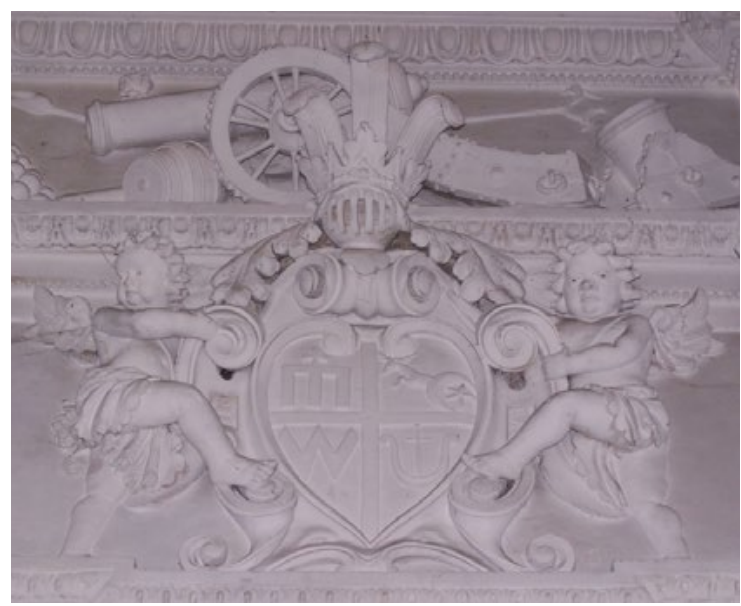

Ryc. 5. Krosno, kaplica Oświęcimów pw. Najśw. Marii Panny i św. Stanisława

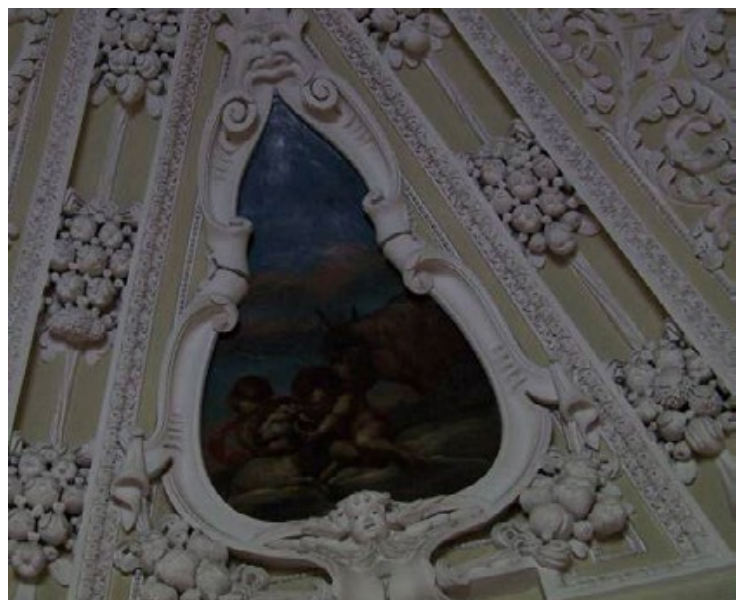

Ryc. 2. Łańcut, zamek gabinet w baszcie północno-zachodniej.

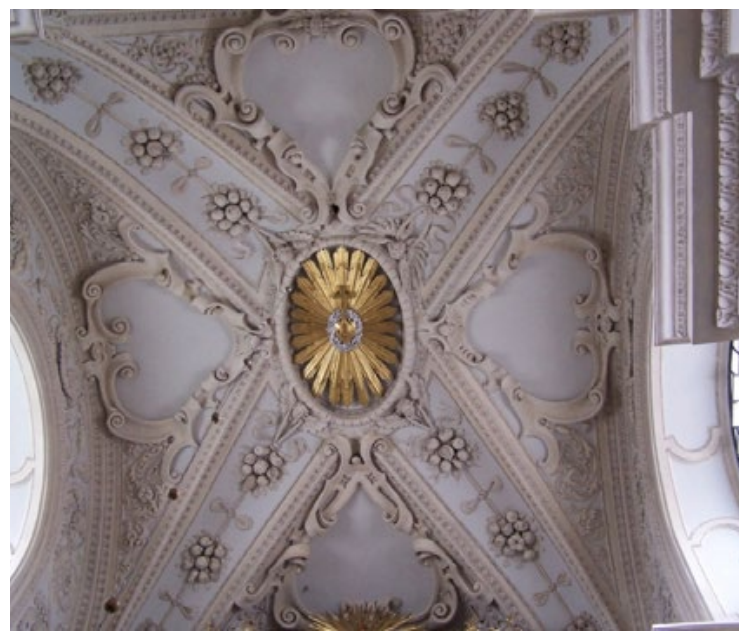

Ryc. 4. Rzeszów. Prezbiterium kościoła Bernardynek (później Pijarów)

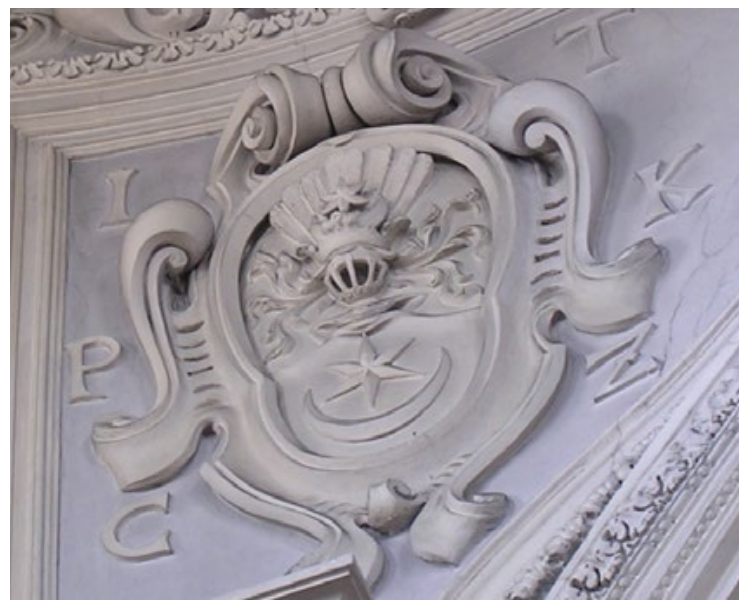

Ryc. 6. Lublin, kaplica Janusza Tyszkiewicza Łohojskiego pw. św. Krzyża 


\section{Ornament figuralny}

Motywy figuralne pełniły funkcję elementu dzielącego w kompozycji sztukatorskiej. W kaplicy w Niepołomicach figury wyrastają z pojedynczych liści i z wici akantu natomiast w kaplicach Podhorcach, Lublinie wtopione są w jego meandryczny splot. Kojarzone są z kartuszami, a także z pękami i girlandami owocowymi, które podtrzymują lub unoszą jak np. w Niepołomicach, w Krośnie. Wielokrotnie wsparte są o konsole, a na głowach dźwigają kosze "wiklinowe” z owocami (Krosno, Rytwiany). Liczne są także przedstawienia główek anielskich uskrzydlonych czy (jak w Łowiczu, Podkamieniu, Lublinie) kobiecych w chustach, które zazwyczaj pełnią funkcje połączeń wiążących inne detale ornamentalne, np. kartusz z ramą, pęki owocowe i girlandy z kartuszami czy ramami lub też motywy te wspierają, unoszą wspomniane detale.

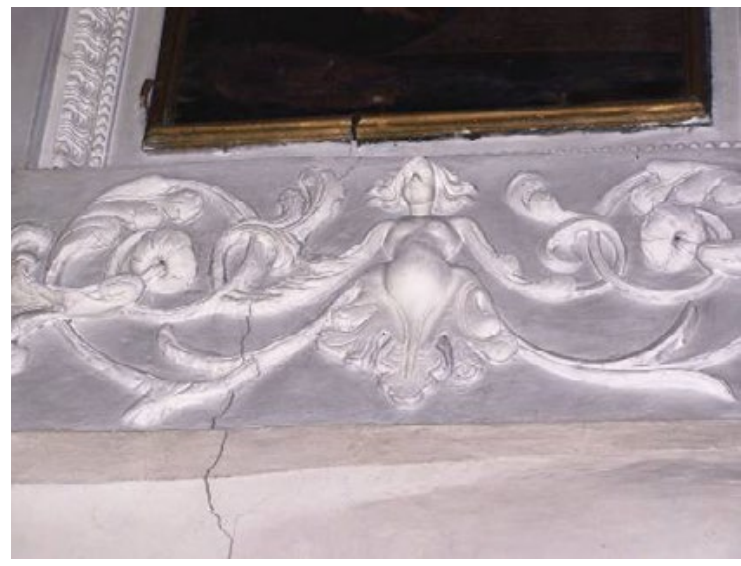

Ryc. 7. Lublin, kaplica Janusza Tyszkiewicza Łohojskiego pw. św. Krzyża

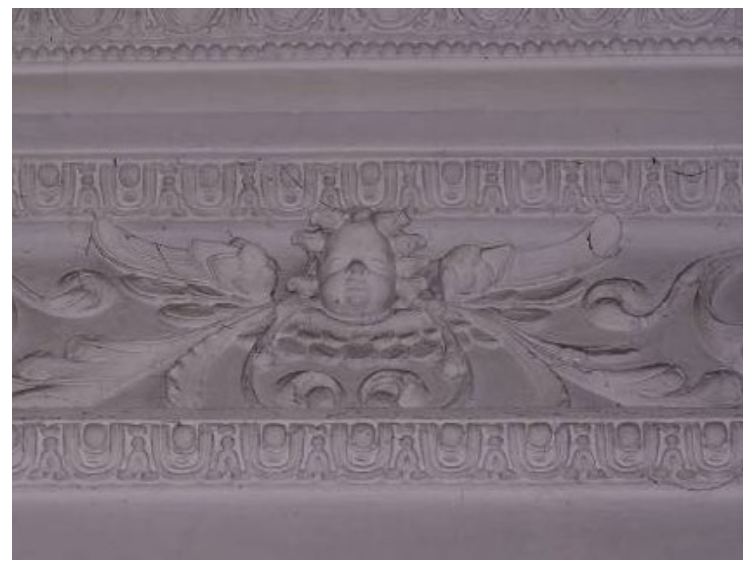

Ryc. 9. Łowicz, nawa główna Kolegiaty pw. Wniebowzięcia Najświętszej Marii Panny i św. Mikołaja.

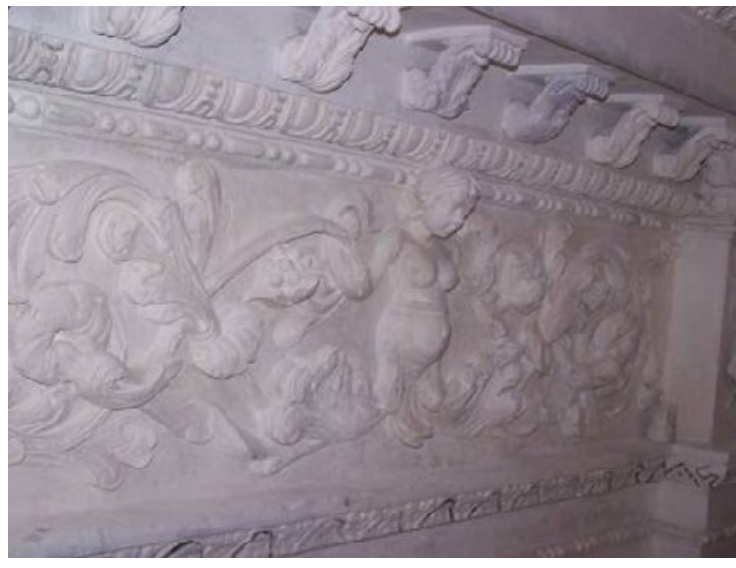

Ryc. 8. Podhorce, kaplica pałacowa pw. Matki Boskiej Bolesnej

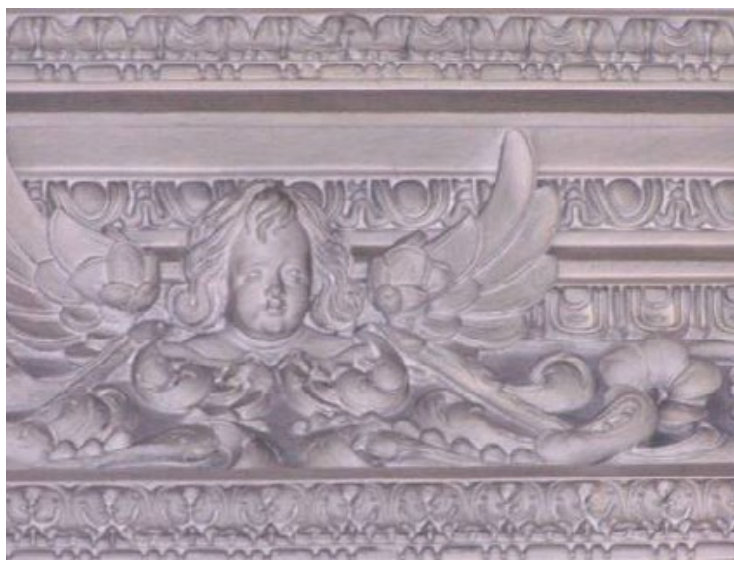

Ryc. 10. Lublin, kaplica Janusza Tyszkiewicza Łohojskiego pw. św. Krzyża. 


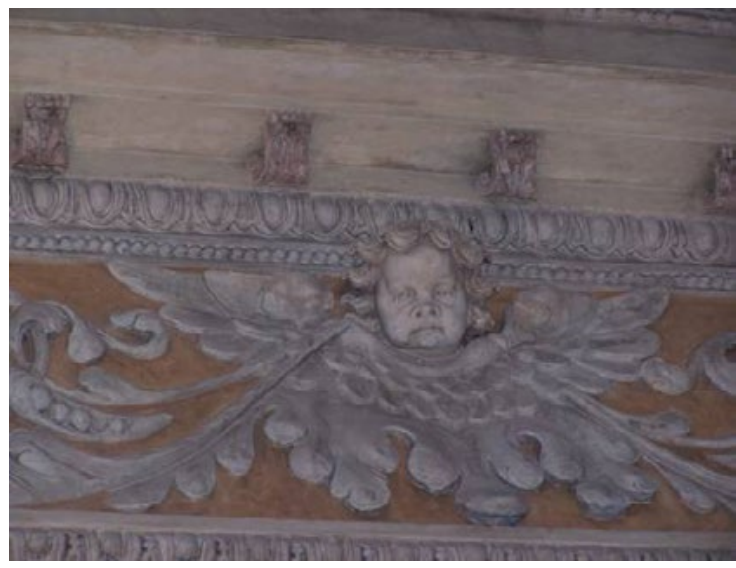

Ryc. 11. Klimontów, prezbiterium kościoła kolegiackiego pw. św. Józefa

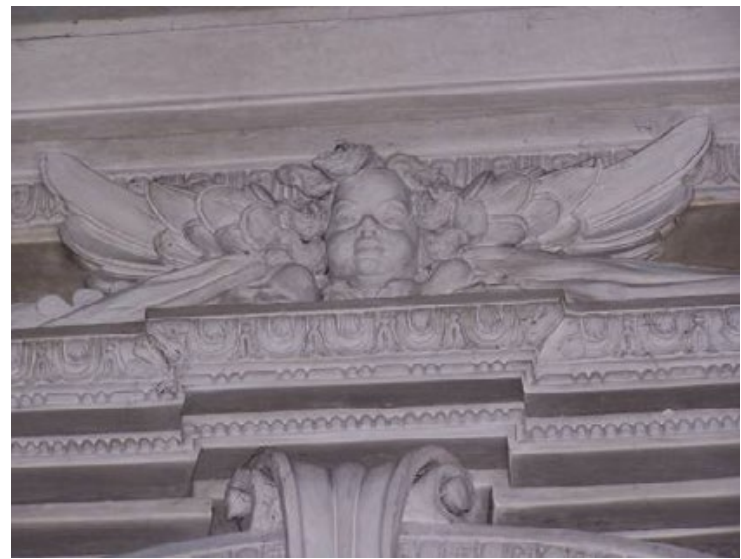

Ryc. 13. Niepołomice, kaplica Lubomirskich pw. św. Karola Boromeusza

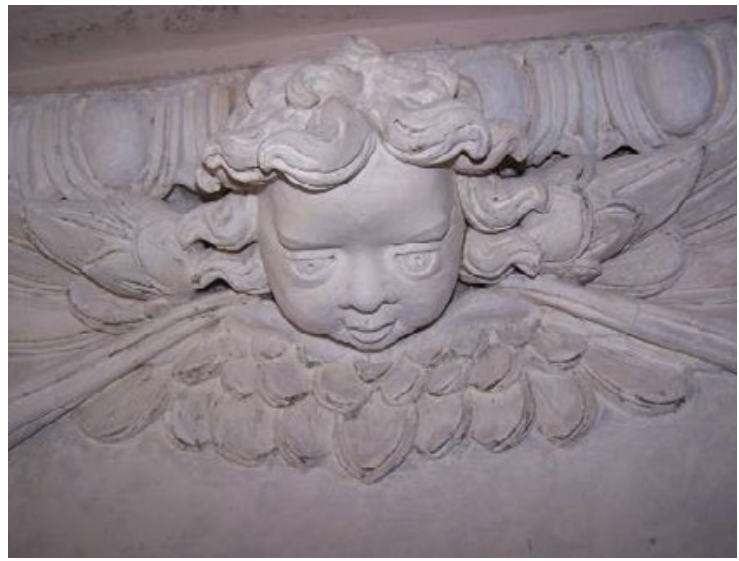

Ryc. 15. Podhorce, kaplica pałacowa pw. Matki Boskiej Bolesnej

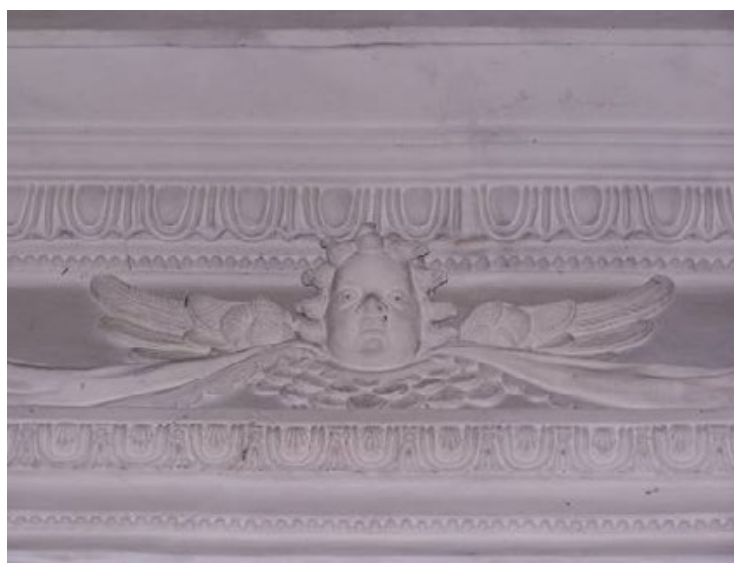

Ryc. 12. Krosno, kaplica Oświęcimów pw. Najśw. Marii Panny i św. Stanisława

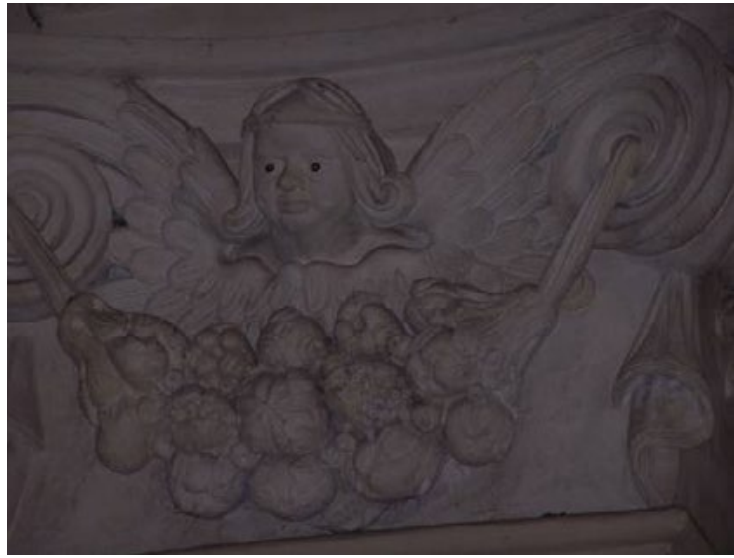

Ryc. 14. Rzeszów, nawa główna kościoła Bernardynek (później Pijarów)

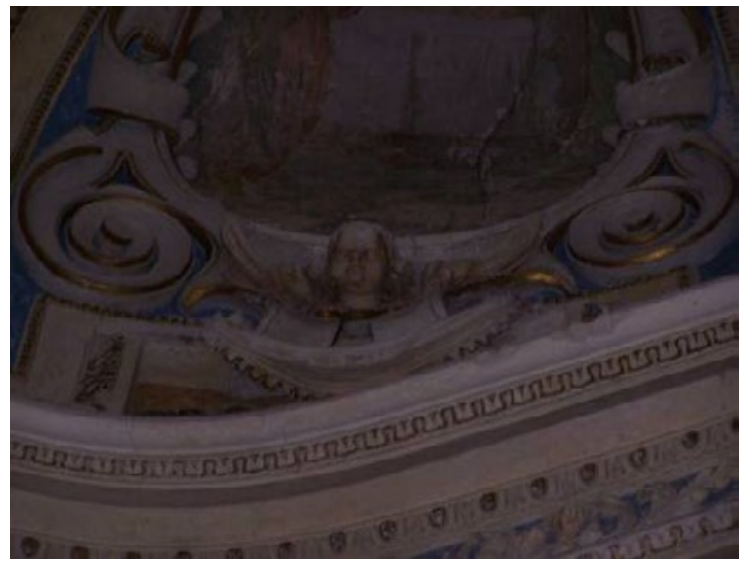

Ryc. 16. Podkamień, kaplica Cetnerów pw. św. Dominika 


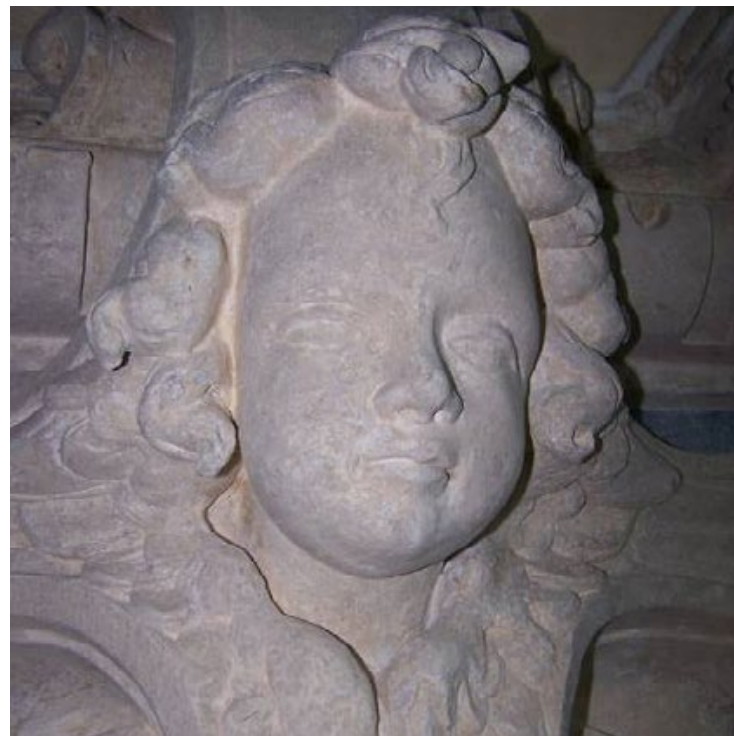

Ryc. 17. Zamość, kaplica Zamoyskich pw. Przemienienia Pańskiego

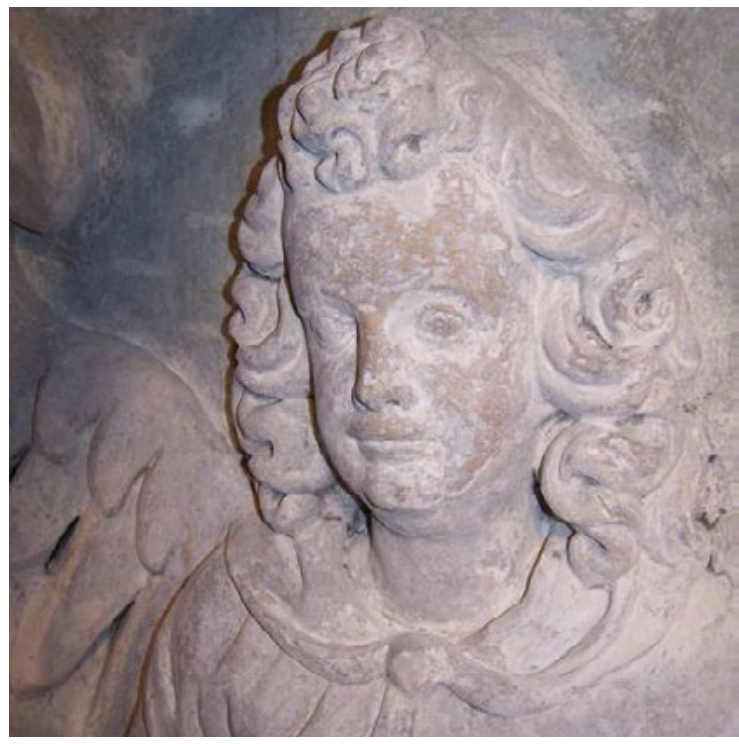

Ryc. 18. Lublin, kaplica Jana Symeona Olelkowicza Słuckiego pw. św. Stanisława Kostki

\section{Ornament roślinny}

Najczęściej występującymi motywami roślinnymi są: pęki i girlandy owocowe, rogi obfitości, liść laurowy, arabeska, wić roślinna i pojedyncze liście akantu tworzące rozety, palmetowe obrzeża szwów sklepiennych, akant (najczęściej w formie wici) kampanule, festony, wieńce kwiatowe i owocowe,

Pęki owocowe najczęściej zawieszone są na kawałku materiału u góry przewiązanego w kokardę lub o rozdzielonych, osobno przymocowanych końcach, w dole przechodzącego formę chwościka. Po bokach pojawiają się dwie pary wijących się wstążeczek. W dekoracji wieży zamku w Łańcucie występują pęki owocowe w liczbie kilku, zawieszonych jedne pod drugimi na tym samym kawałku materiału.

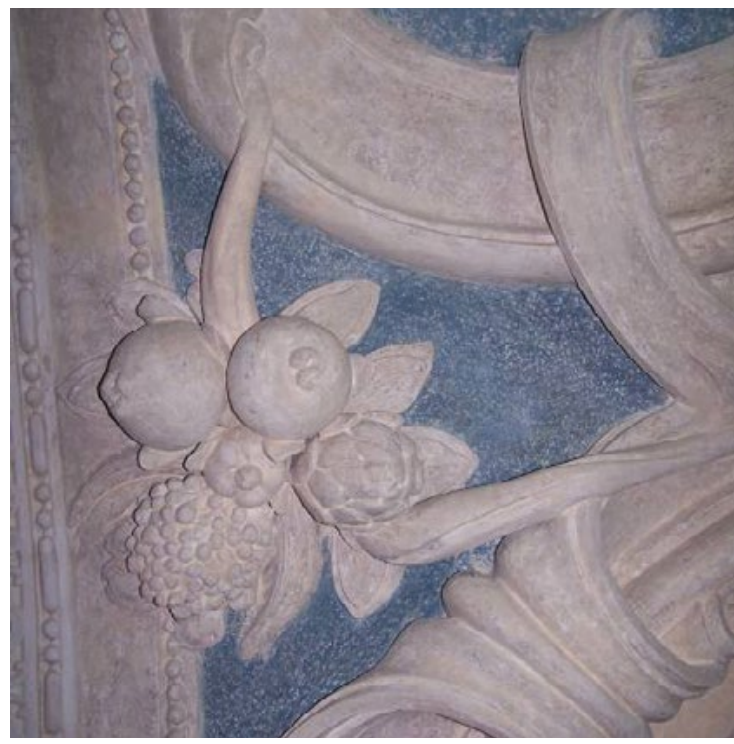

Ryc. 19. Zamość, kaplica Zamoyskich pw. Przemienienia Pańskiego przy kościele kolegiackim

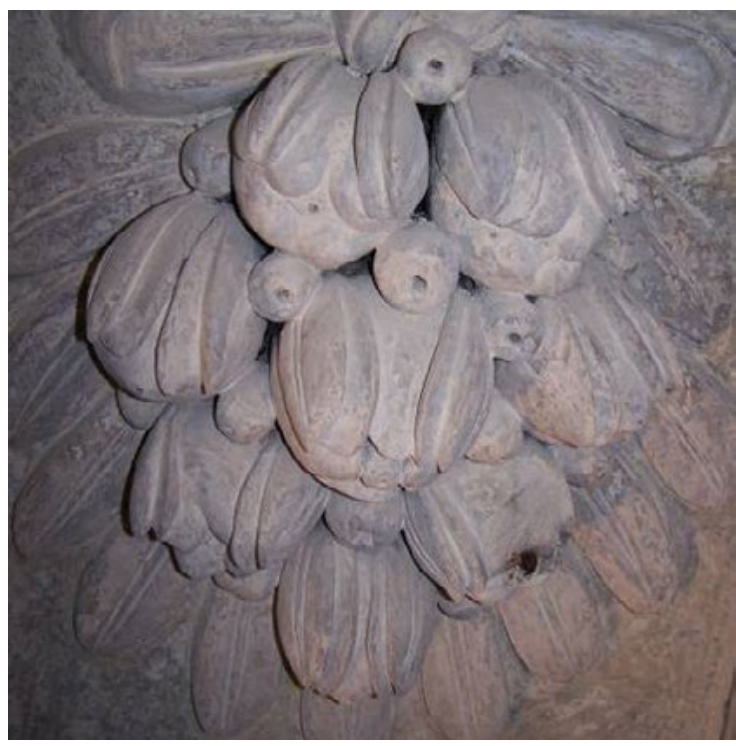

Ryc. 20. Lublin, kaplica Jana Symeona Olelkowicza Słuckiego pw. św. Stanisława Kostki 


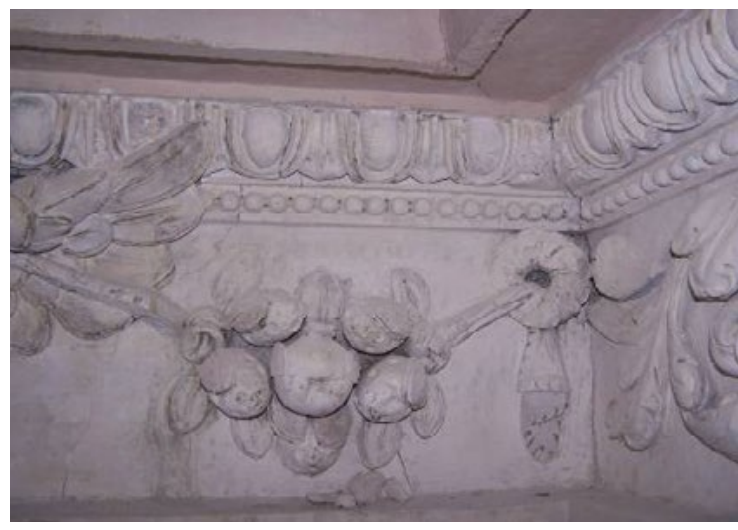

Ryc. 21. Podhorce, kaplica pałacowa pw. Matki Boskiej Bolesnej

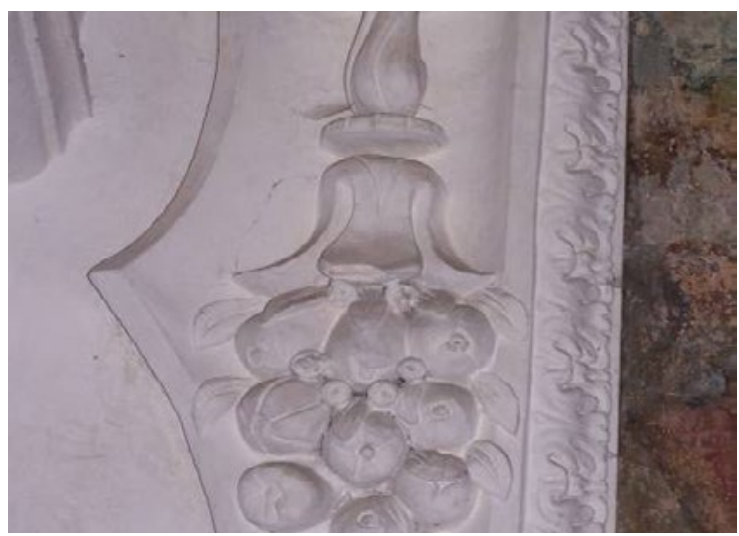

Ryc. 23. Rytwiany. Nawa główna kościoła pw. Zwiastowania Najśw. Marii Panny

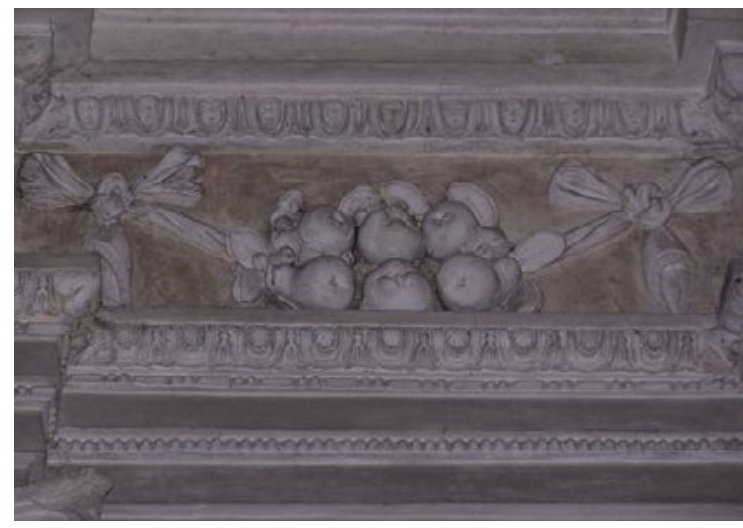

Ryc. 22. Niepołomice, kaplica Lubomirskich pw. św. Karola Boromeusza

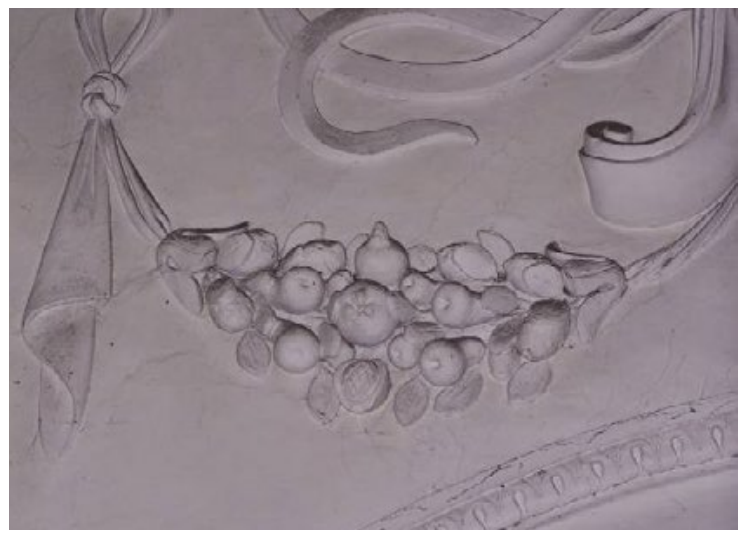

Ryc. 24. Łowicz, prezbiterium kolegiaty pw. Wniebowzięcia Najświętszej Marii Panny i św. Mikołaja

Girlandy owocowe podobnie jak pęki najczęściej podwiązane materiałem z obu końców związanym w kokardę. Owoce, z których ułożone są pęki i girlandy są w przeważającej części pochodzenia południowego. Są to granaty, cytryny, kiście winogron, z rodzimych owoców najczęściej pojawiają się jabłka i gruszki (Kaplice w Podkamieniu i Krośnie). Z biegiem lat owocom coraz częściej i w większej ilości towarzyszą liście i kwiaty.

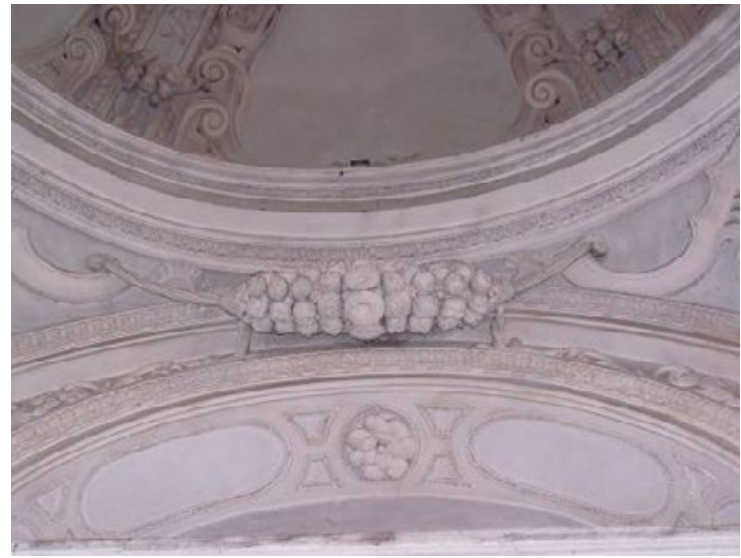

Ryc. 25. Krosno, kaplica Oświęcimów pw. Najśw. Marii Panny i św. Stanisława

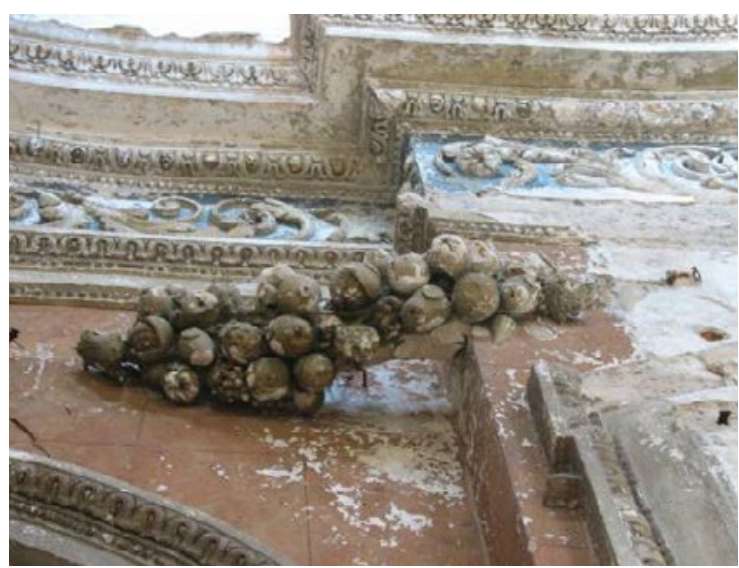

Ryc. 26. Podkamień, kaplica Cetnerów pw. św. Dominika 
Arabeskę najczęściej tworzy wić meandrycznie zwinięta, zdobiąca fryzy, ściany tarczowe i gurty sklepienne bądź buduje szeroka bordiurę dla centralnych ram kompozycji - w tych wszystkich wypadkach komponowana jest zazwyczaj horyzontalnie. Znamy jednak wertykalne zakomponowanie wici roślinnej jak w prezbiterium w Klimontowie czy w podłuczu kaplicy Podkamieniu i u dominikanów w Lublinie. Wić akantową często wkomponowane są motywy figuralne, tworzące wespół z nim formę groteski, także realne przedmioty, muszle, kartusze, pojedyncze liście akantu, rozety a także spinane były przewiązkami, festonami.

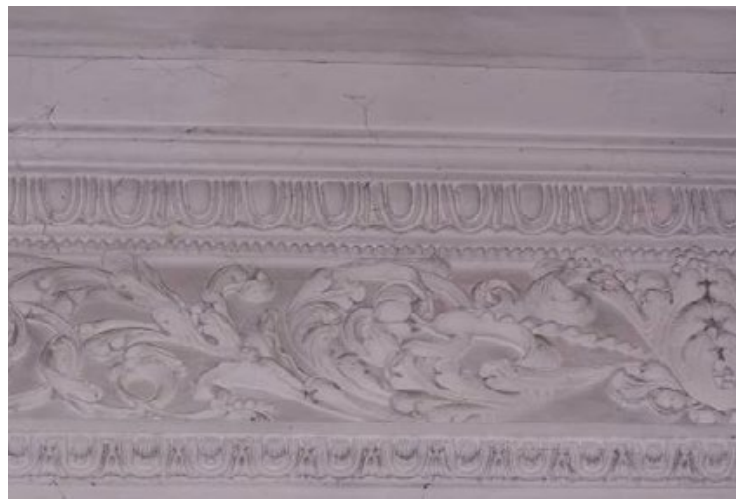

Ryc. 27. Krosno, kaplica Oświęcimów pw. Najśw. Marii Panny i św. Stanisława

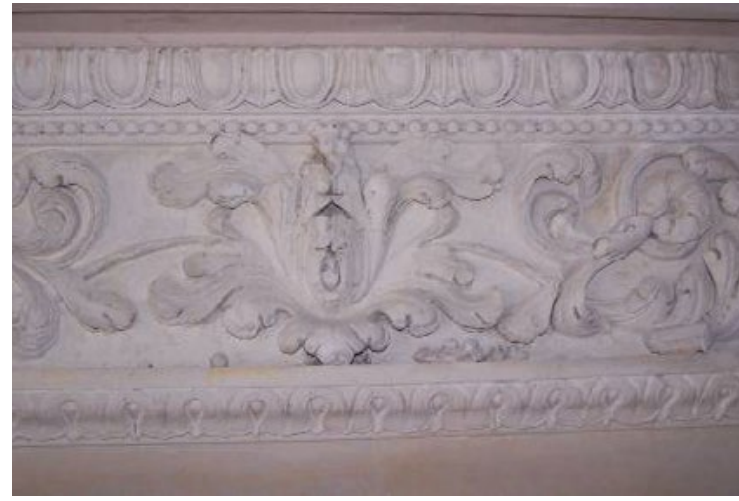

Ryc. 29. Podhorce, kaplica pałacowa pw. Matki Boskiej Bolesnej

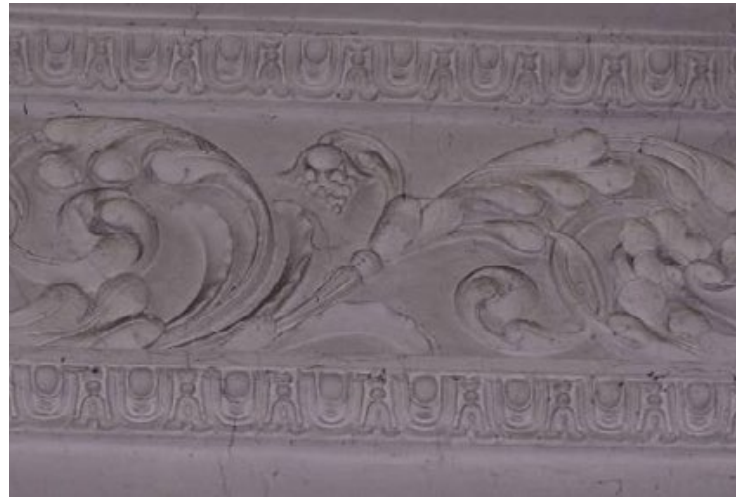

Ryc. 31. Łowicz, prezbiterium kolegiaty pw. Wniebowzięcia Najświętszej Marii Panny i św. Mikołaja

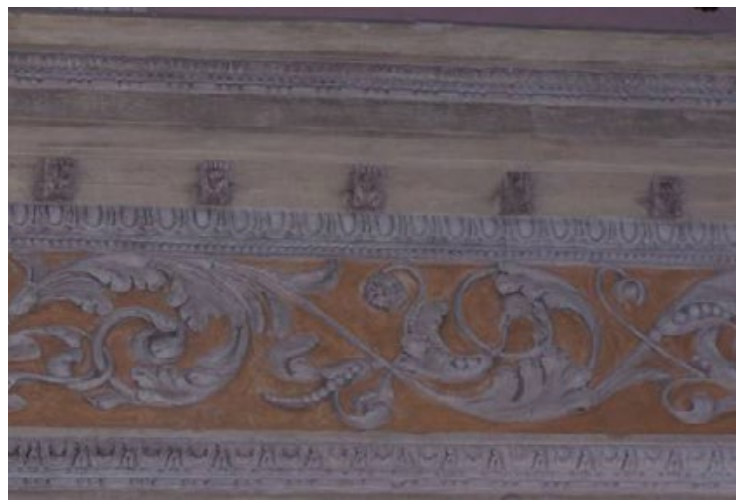

Ryc. 28. Klimontów, prezbiterium kościoła kolegiackiego pw. św. Józefa

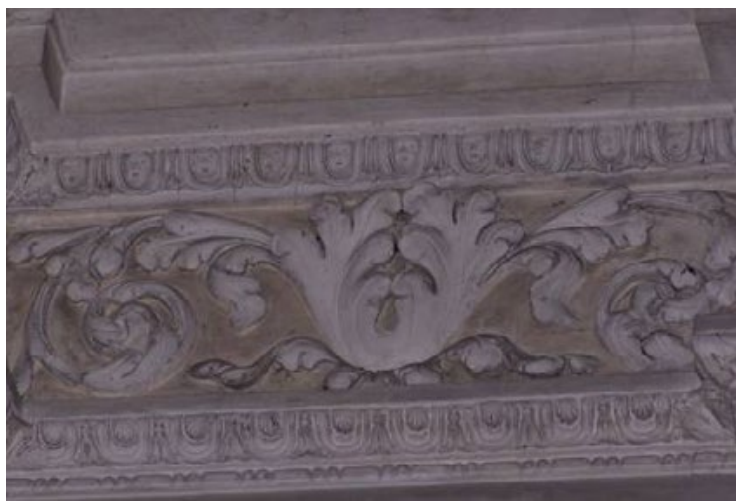

Ryc. 30. Niepołomice, kaplica Lubomirskich pw. św. Karola Boromeusza

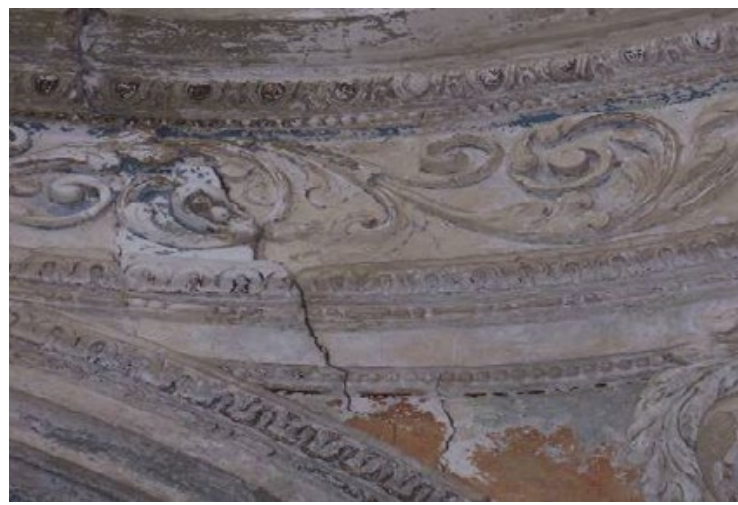

Ryc. 32. Podkamień, kaplica Cetnerów pw. św. Dominika 


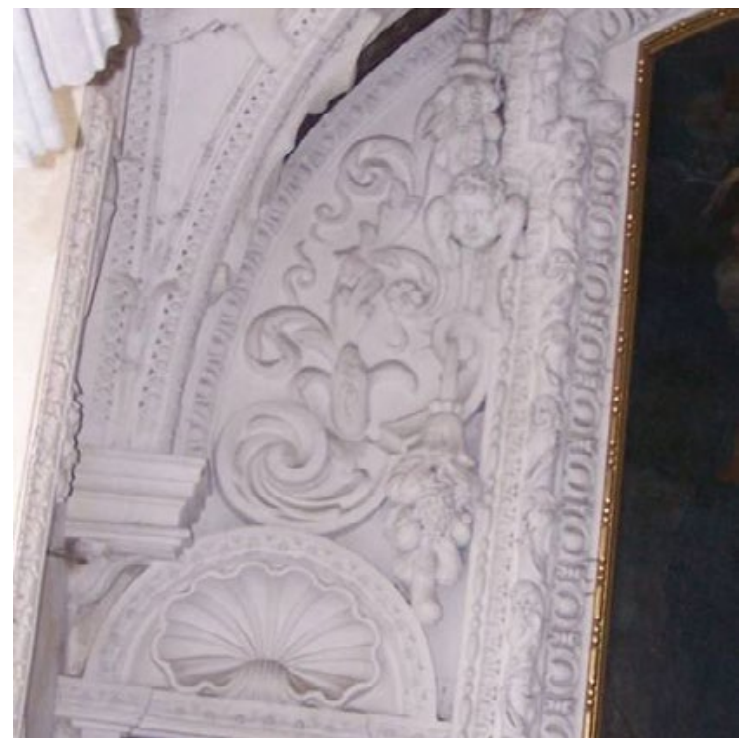

Ryc. 33. Rytwiany. Kaplica przy kościele pw. Zwiastowania Najśw. Marii Panny

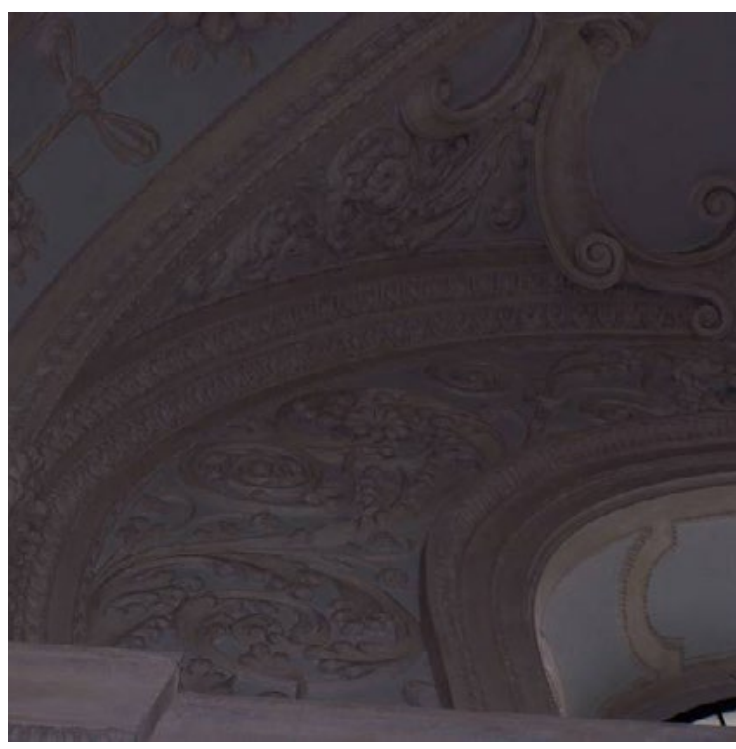

Ryc. 34. Rzeszów. Prezbiterium kościoła Bernardynek (później Pijarów)

Motywy wzorowane na realnych przedmiotach uzupełniają najczęściej wiodące $w$ danej dekoracji typy ornamentu, szczególnie roślinnego. Są to wstążki, kokardy, chwosty, przepaski itp. A także narzędzia Męki Pańskiej unoszone przez anioły (Kaplica Św. Krzyża w Lublinie). Osobną grupę wśród tych motywów stanowią panoplia. Odnajdujemy je w dekoracjach - nowowiśnickiej, zamojskiej, krośnieńskiej i podhoreckiej, prezentują się w nich okazale. Wkomponowane w płyciny są panoplia wojenne - tarcze na tle różnej broni, bębny proporce i różnych rodzajów broni, zbroi w kaplicy Zamościu Panoplia, niektóre motywy figuralne oprócz pełnionych funkcji zdobniczych ilustrują też pewne wątki treściowe, które zazwyczaj rozwijane są poza dekoracjami sztukatorskimi.

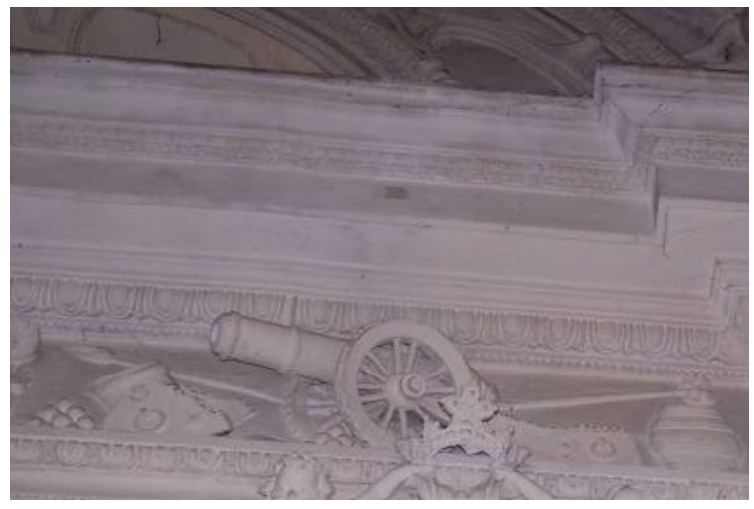

Ryc. 35. Krosno, kaplica Oświęcimów pw. Najśw. Marii Panny i św. Stanisława.

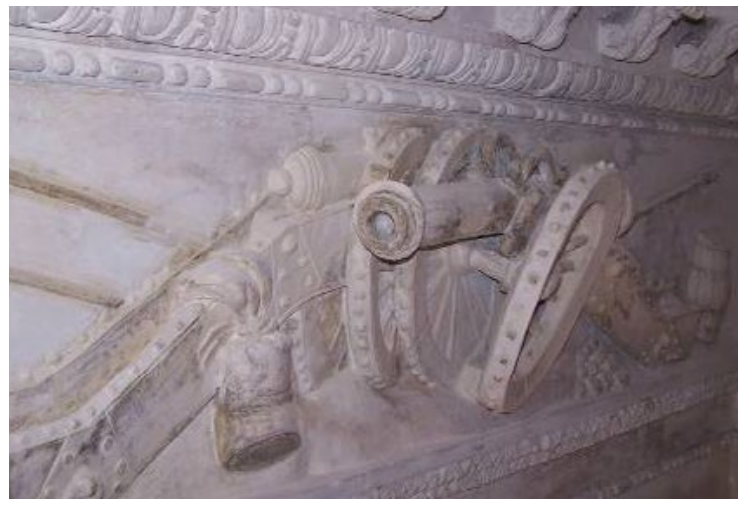

Ryc. 36. Podhorce, kaplica pałacowa pw. Matki Boskiej Bolesnej. 


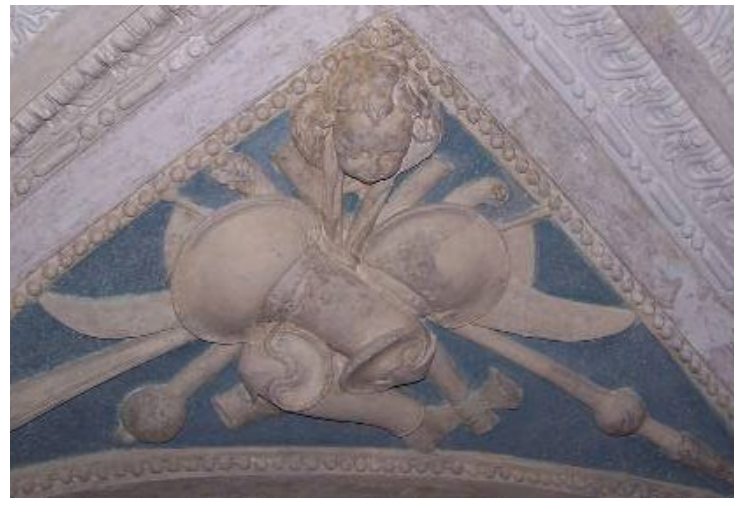

Ryc. 37. Zamość, kaplica Zamoyskich pw. Przemienienia Pańskiego

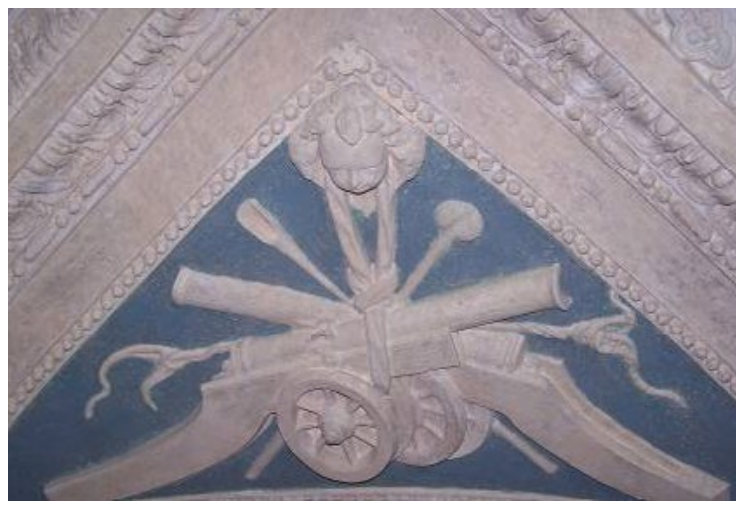

Ryc. 38. Zamość, kaplica Zamoyskich pw. Przemienienia Pańskiego

\section{Podsumowanie}

W przeciwieństwie do układów kompozycyjnych w przypadku ornamentu nie ma tak wyraźnego punktu przełomowego, zwrotnego ornamentyki sztukatorskiej. Jest to związane z dominacją pewnych zestawów ornamentalnych oraz sposobem ich opracowania, które po pewnym czasie ulegają stopniowej zmianie. Większość układów kompozycyjnych dekoracji sztukatorskich, ma charakter przede wszystkim roślinno-abstakcyjno-figuralny, w dekoracjach sztukatorskich dominuje ornamentyka wzorowana na realnych przedmiotach, zespolona albo z motywami roślinnymi albo figuralnymi. Niektóre charakterystyczne dla Falconiego motywy ornamentalne są odmienne w początkowych dekoracjach w detalach i modelunku w końcowych bardziej plastyczne i dynamiczne. Kartusz zawijany początkowo twardo modelowany, jakby na wzór manierystyczny, bardzo szybko jego sploty zawijane stają się miękkie. Równocześnie z kartuszem zawijanym wstępują mięsiste pęki i girlandy owocowe.

Panoplia znane nam z połowy lat 40-tych, na początku modelowane w płaskim reliefie w latach późniejszych stają się bardziej rozbudowane.

Postacie figuralne na początku najczęściej pełnią funkcje kompozycyjne, są ciągle odległym echem figur manierystycznych, a dopiero później zaokrąglają się, są bardziej przysadziste, tracą swój jakby linearny, graficzny modelunek na rzecz płynnego jakby bardziej malarskiego. Postacie wyrastające początkowo z wici roślinnej, po 1640 r. z akantu są z ornamentem roślinnym początkowo dość luźno związane, potem zaś jakby organicznie z niego wyrastają tworząc wespół z nim ruchliwe, urozmaicone i plastycznie opracowane sploty groteskowe.

Wysunięta, przez dotychczasowych badaczy przedmiotu, hipoteza co do włoskiego pochodzenia ornamentu stiukowego, wydaje się w całej rozciągłości potwierdzić. Ornamentem zdecydowanie włoskim jest w całości ornament roślinny, a także ten odwzorowany z realnych przedmiotach. Wśród ornamentyki figuralnej - uskrzydlone główki, nagie putta, maszkarony oraz popiersia są zdecydowanie włoskimi, podobnie jak ornament geometryczny podkreślający podziały sklepienne (astragal, wole oczka). Z wszystkimi tymi detalami spotykamy się już w sztuce antycznej, a przede wszystkim nowożytnej - Rzymu. Również wspomniany zestaw owoców - południowych - jakie pojawiają się w pękach i girlandach potwierdza włoski repertuar ornamentalny. Wydaje się, ze bez względu na włoskie nazwisko sztukatora, repertuar ornamentalny dekoracji sztukatorskich był inspirowany przez manierystyczno-barokowe sztukaterie Rzymu, oraz północno -włoskie okolic Mediolanu i pogranicza włosko-szwajcarskiego. Sztukaterie północno włoskie i z pogranicza szwajcarskiego stały się wzorem dla sztukaterii nie tylko tych powstałych terenie Małopolski, ale prawie dla większości wczesnobarokowych dekoracji sztukatorskich Europy. Mają one podobnie jak Polsce charakter abstrakcyjno-figuralny. Motywami przewodnimi tychże dekoracji są: postać ludzka, najczęściej anielska i kartusze zawijane kształt kartusza północnowłoskiego, jego rama zawijana modelowana miękko wypustkami w rulon nacinany, zdobiony cekinami, podtrzymywany przez putta, a także typ pęków i girland owocowych, mięsista wić roślinna postacie w charakterystycznych rozciętych szatach wsparte o konsole i pilastrowe formy.

Po roku 1640 ornament staje się bardziej mięsisty jakby zaznaczający tektonikę sklepienia, którą jednak podkreśla bezpośrednio poprzez akcentowanie schematów kompozycyjnych dekoracji sztukatorskich, które 
z kolei do wspomnianej tektoniki nawiązują. W ornamencie sztukatorskim tego okresu literatura przedmiotu widzi formy wyrosłe w różnorodnych i czasami sobie przeciwstawnych kręgach artystycznych. Mówi się oczywiście o dalej trwających wpływach włoskich, ale nie wyłącznie północnowłoskich, lecz również związanych z Rzymem, a szczególne z twórczością G.L. Berniniego.

\section{Literatura}

[1] Kurzej M., Siedemnastowieczne sztukaterie w Małopolsce, Kraków 2012.

[2] Klimek B., Warsztat sztukatorski Giovanniego Battisty Falconiego, Lublin 2018.

[3] Teodorowicz-Czerepińska J., Szlak edukacyjno-turystyczny renesansu lubelskiego. Archiwum Wojewódzkiego Urzędu Ochrony Zabytków Lublinie (WOZL), [mps], Lublin 2005.

[4] Chrościcki J. A. , Rola włoskich projektantów i rzemieślników w przemianach sztuki barokowej (Europa Środkowa-Wschodnia), [w:] Barok w Polsce i Europie Środkowo-Wschodniej. Drogi przemian i osmozy kultur, red. J. Pelc, K. Mrówcewicz, M. Prejs, Warszawa 2000, s. 184-185, 190.

[5] Chrościcki J., Kamieniarze i mafiosi. Zarobkowa emigracja z Włoch do Europy Środkowej i Wschodniej (XV-XVIII w.) „Przegląd Humanistyczny" XL, 1996, nr 1, (334), s. 69-85.

[6] Gajewski J., Falconi w Podkamieniu oraz jego dzieła architektoniczno-rzeźbiarskie (problematyka artystyczna i zagadnienie odbioru). „Ikonotheka. Prace Instytutu Historii Sztuki Uniwersytetu Warszawskiego", 5, Warszawa 1993, s. 23-80.

[7] Gębarowicz M., Plastyczne wyposażenie wnętrz. Dekoracje stiukowe i stolarszczyzna [w:] Szkice z historii sztuki XVII wieku "Prace Wydziału Filologiczno-Filozoficznego", 16, z. 3, 1966, s. 67-68.

[8] Karpowicz M., Artisti ticinesi in Polonia nella prima meta del '600, Minano 2002.

[9] Kołaczkiewiczowa E., Wtoskie koneksje ślaskich dekoracji stiukowych, [w:] Nobile Claret Opus. Studia z dziejów sztuki dedykowane Mieczysławowi Zlatowi, Wrocław 1998, s. 340-348.

[10] Kurzej M., Archaizacja i modernizacja. Przemiany stylowe dekoracji sklepiennych na przykładzie kościoła i klasztoru SS. Brygidek w Lublinie, „Roczniki Humanistyczne”, 54, 2006, z. 4, s. 148-187.

[11] Kurzej M., Jan Wolff. Monografia architekta w świetle analizy prefabrykowanych elementów dekoracji sztukatorskich, Kraków 2009.

[12] Kurzej M., Między narodzinami, śmiercią a zbawieniem - próba interpretacji sztukaterii w Tarłowie [w:] Studia nad sztuką renesansu i baroku, 10, red. J. Lileyko, I. Rolska-Boruch, 2010, s. 183-188.

[13] Kurzej M., Podkamień i Lublin - dekoracje sztukatorskie warsztatu Falconiego w kościołach dominikańskich, [w:] Dominikanie na ziemiach polskich w epoce nowożytnej, red. A. Markiewicz, M. Miławicki (Studia i źródła Dominikańskiego Instytutu Historycznego, t. 5), s. 425-454.

[14] Lewicki J., Stropy ramowe w Polsce, cz. 2, „Kwartalnik Architektury i Urbanistyki”, 40, 1995, z. 3-4, s. 222-224.

[15] Łoziński J. Z., Grobowe kaplice koputowe w Polsce 1520-1620, Warszawa 1973, s. 174.

[16] Majewski K., Wzorek J., Twórcy tzw. renesansu lubelskiego w świetle nowych badań, „Biuletyn Historii Sztuki”, 31, 1969, s. $127-131$.

[17] Majewski K., Wzorek J., Z badań nad rozwojem architektury w Lublinie w 1 połowie XVII wieku, [w:] Rocznik Lubelski, XII, 1970, s. 59-90.

[18] Miłobędzki A., Architektura polska XVII wieku, Album ilustracji, Warszawa 1980.

[19] Preiss P., Italštiumělci v Praze, Praha 1986, s. 254. 